\title{
Clinicopathological analysis of recurrent basal cell carcinoma of the eyelid
}

\author{
Aleksandra Iljin ${ }^{1}$, Tomasz Zieliński ${ }^{1}$, Bogusław Antoszewski ${ }^{1}$, Stanisław Sporny² \\ ${ }^{1}$ Department of Plastic, Reconstructive and Aesthetic Surgery, Institute of Surgery, Medical University of Lodz, Lodz, Poland \\ ${ }^{2}$ Department of Dental Pathology, Medical University of Lodz, Lodz, Poland \\ Adv Dermatol Allergol 2016; XXXIII (1): 42-46 \\ DOI: 10.5114/pdia.2015.48039
}

\begin{abstract}
Introduction: Basal cell carcinoma (BCC) is the most common malignant neoplasm of the eyelids and surrounding structures, usually developing in the area of the lower lid and medial canthus. Invasive forms of BCC are connected with a high risk of recurrence, often due to incomplete excision of these lesions.

Aim: Clinical and pathological analysis of recurrent BCCs of the eyelids and surrounding structures.

Material and methods: We present clinical and pathological analysis including immunohistochemical reaction to Ki-67 antigen of 19 patients (11 women, 8 men) operated for recurrent BCCs of the eyelids in 2000-2012.

Results: In most cases, recurrences were present on the lower lid and in the medial canthus. In 15 patients the histopathological type did not change and in 4 cases it transformed into more invasive forms. The values of Ki-67 index for primary BCCs ranged between $1 \%$ and $20 \%$, and for relapsing lesions between $11 \%$ and $48 \%$.

Conclusions: Proper clinical and pathological evaluation to determine the risk of relapse in BCCs of the eyelids and surrounding structures should include the analysis of prognostic factors, in particular location and size, histopathological type and radicalness of surgical treatment of primary BCCs. Clinical and pathological analysis of patients with recurrent BCC of the eyelids and surrounding structures should be combined with the evaluation of proliferation index Ki-67, which is essential for prognosis and choice of the appropriate therapeutic method.
\end{abstract}

Key words: recurrent BCC, eyelid, Ki-67 antigen.

\section{Introduction}

Ninety percent of skin cancers are localized within the head and neck region. In 10\% of patients they comprise the eyelids, and are most common in the elderly patients $[1,2]$. In the etiology of these neoplasms environmental and socioeconomic factors have been implied. The significant effect of exposure to ultraviolet radiation, ionizing irradiation, arsenic or immunosuppressive drugs has been stressed. Frequently conditions predisposing to skin cancer development include solar keratitis (senile keratitis), pigmented parchment skin, Gorlin-Goltz syndrome, Bowen disease, acanthocellular keratoma, or chronic skin ulcers. The most common malignant neoplasms of the eyelids and surrounding structures are: basal cell carcinoma (BCC) (80-90\%), squamous cell carcinoma (4-10\%), adnexal cancer - mainly sebaceous (5\%) and malignant melanoma (1\%) [3-7]. Suggested classification systems of malignant skin tumors include both clinical and macroscopic features. Currently, the WHO classification of 2006 is recommended [8].
Basal cell carcinoma usually involves the lower eyelid and medial canthus, presenting many histological types including superficial, infiltrating, nodular, and with adnexal differentiation. It usually manifests as a single lesion, often with ulceration, or central scarring and peripheral keratosis. It may show deep infiltration. Tumors spreading outside their macroscopic borders, with a high rate of growth, are connected with a higher incidence of relapses, and incomplete surgical removal. Involvement of the eye socket and intracranial penetration of BCC are associated with poor prognosis [2, 3, 4, 9].

On average, 1 in every 10 BCCs relapses [10]. The main reason for relapse is incomplete surgical excision. Basal cell carcinoma cells present in the so-called positive margins are usually only demonstrated in the microscopic evaluation of the removed tumor. The most invasive histological types of BCC are connected with the highest risk of relapse. In $26.5 \%$ of patients with an infiltrating type, BCC recurrence is observed, while in the nodular type it is seen in only $6.4 \%$ of patients and in the su-

Address for correspondence: Aleksandra Iljin, 70/129 Lutomierska St, 91-037 Lodz, Poland, phone: +48 $426517062,+48660422740$, fax: +48 4267767 49, e-mail: oiljin@poczta.onet.pl Received: 27.04.2014, accepted: 17.07.2014. 
perficial type in $3.6 \%$ of cases. The anatomical location of the tumor often makes complete excision difficult, in particular in lesions situated on the eyelids and in the canthus. Recurrent lesions appear within the first 3 years after primary operation, on average, and $20 \%$ of relapses are diagnosed $6-10$ years after excision of the original lesion. In these patients second relapse is observed in $40 \%$ of cases [11].

The treatment of recurrent BCCs of the eyelids and surrounding structures, especially infiltrating and involving the lower lid and medial canthus, is usually much more problematic than the treatment of the primary lesions. The evaluation of the risk of relapse based on the clinicopathological features is of limited value. The role of immunoexpression of epithelial growth factor (EGFR) and proliferation index Ki-67 in establishing proper prognosis and choice of further therapy has been stressed [2, 3, 12-14].

\section{Aim}

Clinical and pathological analysis of recurrent BCCs of the eyelids and surrounding structures.

\section{Material and methods}

In 2000-2012 we operated on 173 patients with primary BCC of the eyelids and surrounding structures. In 19 patients from this group (11 females, 8 males) aged 54-79 years, the recurrent neoplastic process was noted after complete surgical excision. In all cases, surgical treatment consisted of excision of the lesion with a margin of macroscopically normal skin and reconstruction during the same procedure. The lesions were verified pathologically according to the WHO classification of 2006.

Tissue samples obtained during surgery were fixed in $10 \%$ neutral formalin solution and, after marking the incision lines with ink, underwent routine histological examination. At the same time in each case of BCC standard $A B C$ technique was used for immunohistochemical determination of Ki-67 antigen expression, using antibodies against MIB-1 from DAKO. Microscopic analysis was performed using the optic microscope Olympus
BX41 combined with a computer image analyzer. The proliferation index Ki-67 was assessed by counting stained cellular nuclei of BCC cells per 1000 visible neoplastic cells.

The site and clinical stage of recurrent lesions, as well as age and general condition of patients determined the choice of the reconstructive method. To cover the postoperative defect, various methods were used: flaps from cheeks (BCC of the lower lid), flaps from the forehead and free skin graft (BCC of the medial canthus) (Figure $1 \mathrm{~A}-\mathrm{C}$ ). The patients were followed up to monitor oncological, functional and esthetic results of treatment for the next few years, with visits every 6 months.

\section{Results}

In 7 patients, a recurrent lesion was detected within the lower eyelid. The presence of relapses involving the eye canthi was noted in 12 cases: in 2 patients of the lateral canthus, and in 10 patients of the medial canthus. In the analyzed group there were 8 women and 11 men. The majority (18 patients) were in their $7-8^{\text {th }}$ decade of life.

Primary BCCs showed various microscopic pictures: nodular (8 patients), adnexal with trichilemmal differentiation (5), mixed nodular-infiltrating (2), infiltrating (2) and superficial (2).

In 15 cases the histological type of recurrent BCC did not differ from the original lesion (Table 1).

In recurrent BCCs the most common was the nodular type (6 patients) and adnexal with trichilemmal differentiation (5 patients), also nodular-infiltrating (2 cases) and infiltrating (2 cases).

In 2 patients, a change of the BCC type from nodular to infiltrative was noted, and in 2 cases from the superficial to nodular type.

Proliferation index Ki-67 values were within the $1-20 \%$ range for primary BCCs, and $11-48 \%$ range for recurrences (Table 1). They were usually higher in recurrent BCCs (18 cases) than in primary lesions. Only in 1 woman aged 54 years with nodular BCC of the lateral eye canthus, Ki-67 index in the primary tumor was higher (20\%) than in the recurrent lesion (13\%). Detailed analysis is shown in Table 1.
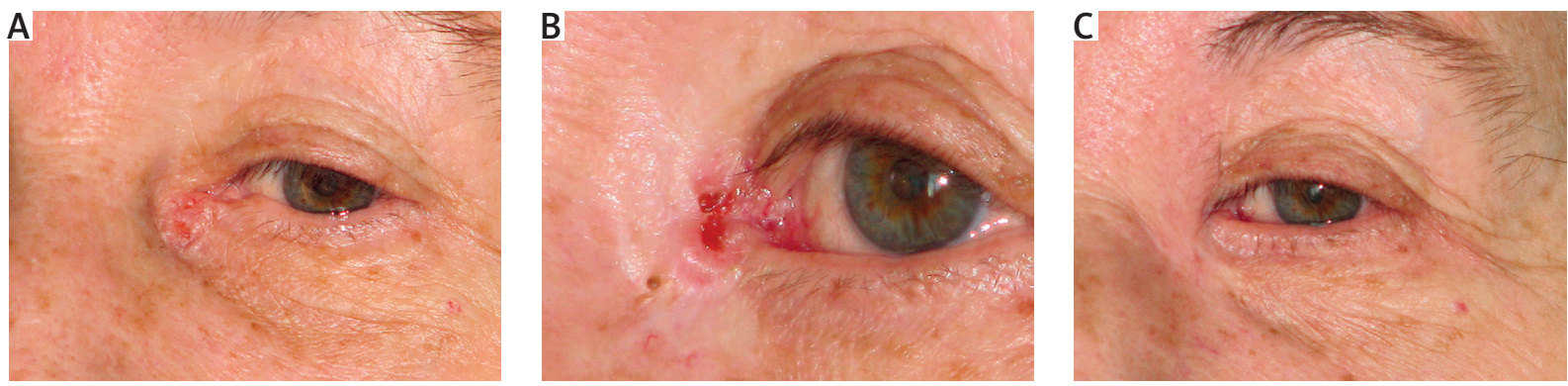

Figure 1. A - Primary focus of BCC within medial canthus. B - Recurrence of the tumor after 3 years from excision. $\mathrm{C}$ - Status after recurrent tumor excision and reconstruction with the use of the glabellar flap 
Table 1. Characteristics of patients re-operated for recurrent BCCs of the eyelids

\begin{tabular}{|c|c|c|c|c|c|c|c|c|}
\hline Gender & $\begin{array}{c}\text { Age } \\
\text { [years] }\end{array}$ & $\begin{array}{l}\text { Topographic } \\
\text { location }\end{array}$ & $\begin{array}{l}\text { Histopathology } \\
\text { of primary lesion }\end{array}$ & $\begin{array}{l}\text { Histopathology } \\
\text { of secondary } \\
\text { lesion }\end{array}$ & $\begin{array}{l}\text { IP of } \\
\text { primary } \\
\text { lesion } \\
\text { [\%] }\end{array}$ & $\begin{array}{l}\text { IP of } \\
\text { secondary } \\
\text { lesion } \\
{[\%]}\end{array}$ & $\begin{array}{l}\text { Time span } \\
\text { to confirmed } \\
\text { recurrence } \\
\text { [months] }\end{array}$ & $\begin{array}{l}\text { Postoperative } \\
\text { period } \\
\text { free from } \\
\text { recurrences } \\
\text { [years] }\end{array}$ \\
\hline M & 78 & $\begin{array}{c}\text { Medial } \\
\text { canthus RE }\end{array}$ & \multirow{5}{*}{\multicolumn{2}{|c|}{$\begin{array}{l}\text { BCC with trichilemmal } \\
\text { differentiation }\end{array}$}} & 8 & 26 & 16 & 2 \\
\hline $\mathrm{F}$ & 70 & Le RE & & & 8 & 11 & 8 & 1 \\
\hline M & 71 & $\begin{array}{c}\text { Medial } \\
\text { canthus LE }\end{array}$ & & & 5 & 15 & 13 & 3 \\
\hline $\mathrm{F}$ & 74 & Le LE & & & 6 & 13 & 9 & 2 \\
\hline M & 73 & $\begin{array}{c}\text { Medial } \\
\text { canthus LE }\end{array}$ & & & 10 & 29 & 18 & 3 \\
\hline $\mathrm{F}$ & 61 & Le LE & \multirow{6}{*}{\multicolumn{2}{|c|}{ BCC - nodular type }} & 7 & 14 & 7 & 3 \\
\hline $\mathrm{F}$ & 54 & $\begin{array}{c}\text { Lateral } \\
\text { canthus RE }\end{array}$ & & & 20 & 13 & 8 & 1 \\
\hline$F$ & 65 & $\begin{array}{c}\text { Medial } \\
\text { canthus RE }\end{array}$ & & & 10 & 18 & 18 & 1 \\
\hline $\mathrm{F}$ & 60 & $\begin{array}{c}\text { Medial } \\
\text { canthus LE }\end{array}$ & & & 12 & 21 & 16 & 2 \\
\hline M & 70 & $\begin{array}{c}\text { Medial } \\
\text { canthus RE }\end{array}$ & & & 9 & 15 & 14 & 3 \\
\hline M & 69 & $\begin{array}{c}\text { Medial } \\
\text { canthus LE }\end{array}$ & & & 14 & 28 & 20 & 3 \\
\hline $\mathrm{F}$ & 79 & $\begin{array}{c}\text { Medial } \\
\text { canthus LE }\end{array}$ & \multirow{2}{*}{\multicolumn{2}{|c|}{ BCC - nodular-infiltrating type }} & 18 & 25 & 30 & 2 \\
\hline $\mathrm{F}$ & 74 & $\begin{array}{c}\text { Medial } \\
\text { canthus RE }\end{array}$ & & & 15 & 27 & 15 & 3 \\
\hline $\mathrm{F}$ & 73 & $\begin{array}{l}\text { Lateral } \\
\text { canthus LE }\end{array}$ & \multirow{2}{*}{\multicolumn{2}{|c|}{ BCC - infiltrating type }} & 1 & 12 & 23 & 9 \\
\hline M & 70 & Le RE & & & 5 & 20 & 18 & 5 \\
\hline $\mathrm{F}$ & 73 & $\begin{array}{c}\text { Medial } \\
\text { canthus LE }\end{array}$ & \multirow[t]{2}{*}{$\begin{array}{c}\text { BCC - superficial } \\
\text { type }\end{array}$} & \multirow[t]{2}{*}{$\begin{array}{l}\text { BCC - nodular } \\
\text { type }\end{array}$} & 6 & 39 & 21 & 3 \\
\hline $\mathrm{F}$ & 68 & Le LE & & & 10 & 48 & 15 & 3 \\
\hline M & 72 & Le LE & \multirow{2}{*}{$\begin{array}{l}\text { BCC - nodular } \\
\text { type }\end{array}$} & \multirow{2}{*}{$\begin{array}{c}\text { BCC - infiltrating } \\
\text { type }\end{array}$} & 7 & 17 & 5.5 & 4 \\
\hline M & 75 & Le RE & & & 10 & 24 & 7 & 4 \\
\hline
\end{tabular}

$I P$-proliferation index, $M$ - male, $F$-female, Le - lower eyelid, $R E$ - right eye, $L E$ - left eye.

\section{Discussion}

Basal cell carcinoma, as the most common cancer of the eyelids and surrounding structures, even after radical resection is connected with a $2-5 \%$ risk of recurrence, which increases to $32-38 \%$ if excision was not complete $[15,16]$.

The histopathological structure of BCC, especially in intensely infiltrating forms, makes oncological purity difficult to achieve. It is demonstrated by a high number of relapses, occurring in 50\% of lesions excised completely, according to some authors [17]. The microscopic picture of a recurrent lesion is less clear for a pathologist, due to severe proliferation of the connective tissue during scar formation, which impairs accurate evaluation of the extent of BCC infiltration $[17,18]$.

The morphology of relapsed lesions in the study group, which comprised $11 \%$ of completely excised primary cancers of the eyelids and surrounding tissues in our centre, was consistent with BCC.

According to other authors, eyelids and surrounding tissues are especially prone to recurrences [9], which has been confirmed by their location in the present group of patients. It involves especially the lower lid and medial canthus, where we observed lesions in 17 patients (89.47\%). 
In our opinion, precise prognosis of the time of potential relapses is not possible, which has been confirmed by other authors. In patients from our study group, recurrence appeared within 8 to 30 months from the primary operation. Similarly to other authors, we observed that women, who prevailed on our group (58\%), consult a doctor sooner, suspecting a relapse. Elderly patients delay their visits, and their evaluation of their clinical condition is often not objective [17].

In complete resections clinical verification of potential relapses is decisive, while in the case of incomplete resection the following factors are important: location, size and histological type of tumor, but also general factors such as the immune status of the patient. The area of the nose, eye lids - in particular the lower lid and medial canthus, nasolabial folds, ears, chin and mandible are connected with a higher risk of relapses in more aggressive microscopic forms of BCC. Similarly, less invasive forms, if incompletely excised, may require reoperation due to specific location [19]. Many authors report a relatively low (10\%) percentage of relapses after incomplete resection of less aggressive BCCs and about $20 \%$ in more invasive forms $[18,20]$.

Residual cancer cells tend to regress spontaneously, and in the postoperative period are usually eliminated by reparative and inflammatory processes. This explains a low risk of relapse. Some authors claim that spontaneous regression is possible only in a small number of BCC cells, and deny the effect of the above mentioned processes. Larger tumors and presence of skin adnexa in the operated area makes complete resection more problematic, which translates into a higher risk of relapse, more frequent in the head than in the limbs and trunk $[17,21]$. The tendency to spread along peripheral nerves, observed in some BCCs, also poses a significant risk.

Data presented by other authors differ as to the occurrence of recurrent lesions for some types of BCC: according to Saxton, in infiltrative $-26 \%$, in nodular $-6.4 \%$, in superficial $-3.6 \%$, and according to Zagrodnik, in infiltrative $-27.7 \%$, in nodular $-8.2 \%$, in superficial $-26.1 \%$ $[22,23]$. In our group of patients we observed relapses of some types of BCCs presenting identical morphology as primary tumors.

The recurrence tends to be more aggressive, sometimes with transformation into a different histomorphological form $[3,17]$. The results of our studies indicate that in 4 patients relapses had more aggressive morphological picture than primary BCCs, as in 2 cases the original lesion transformed from the superficial into nodular type (10.53\%), and in 2 cases from nodular into infiltrating.

Cellular kinetics of the neoplasm directly changes the clinical course of the process. Determination of proliferation activity is a good indicator of the invasiveness of the neoplasm, which provides important prognostic information. Also, it is often important for the qualification of the patient to adjuvant surgical treatment, as high pro- liferation index reflects sensitivity of cancer cells to radioand chemotherapy. The antigen Ki-67 determined by us during microscopic analysis, is connected with cellular proliferation. Its presence has been demonstrated in all phases of the cellular cycle (G1, S, G2 and M) in dividing cells, except for G0 phase. In the majority of publications, a strong correlation between the immunoreactivity of Ki-67 and microscopic malignancy of the neoplasm has been demonstrated. Taking into account, apart from a high prognostic value of Ki-67 expression, that the procedure is simple and repeatable, this method should be recommended for objective evaluation of proliferative activity of malignant neoplasms in various organs in everyday diagnostic practice [24]. The values of Ki-67 index obtained in our study showed that usually the value was higher in the relapsed BCCs, than in the primary lesion. Only in 1 case it was a reverse correlation. We did not prove, however, any correlation between microscopic BCC picture and time to relapse, and $\mathrm{Ki}-67$ value. The utility of this parameter in the clinical practice, as a real prognostic marker, is not clear. Our study group, however, did not comprise a high number of patients, and it may have influenced the results of our observation.

It should be stressed that although BCC is characterized by a strong local malignancy, it may also metastasize, but the likelihood of this is quite low. In patients with this type of skin cancer, the risk of metastases is positively correlated with the size of lesion and depth of infiltration. The microscopic type of tumor is, however, not so important. The risk of metastases increases if the resection was combined with radiotherapy. In BCCS larger than $3 \mathrm{~cm}$, the risk of metastasis is about $1-2 \%$, while in tumors over $5 \mathrm{~cm}$ in diameter it reaches $20-25 \%$. In general, BCCs that appeared in humans younger than 35 years are connected with worse prognosis [11]. In our patients there were no relapses in this age group. Recurrences developed in the majority of cases in elderly patients with tumors less than $3 \mathrm{~cm}$ in diameter. It is possible that the proliferation index $\mathrm{Ki}-67$ in large BCCs would become a sensitive prognostic tool. In our opinion, the standard algorithm of postoperative pathological examination should include evaluation of the proliferation index Ki-67. In skin cancers it should be at least recommended, as final conclusions can only be drawn on the basis of the analysis of a large series of patients.

\section{Acknowledgments}

The study was conducted at the Department of Plastic, Reconstructive and Aesthetic Surgery, Medical University of Lodz, and the Department of Dental Pathology, Medical University of Lodz.

\section{Conflict of interest}

The authors declare no conflict of interest. 


\section{References}

1. Coroi M, Rosca E, Mutiu G, et al. Eyelid tumors: histopathological study performed in County Hospital of Oradea between 2000-2007. Rom J Morphol Embryol 2010; 51: 111-5.

2. Zieliński T, Pisera P, Siewiera I, et al. Chirurgiczne leczenie złośliwych nowotworów powiek. Pol Merk Lek 2013; 34: 214-8.

3. Zieliński T, Iljin A, Antoszewski B. Nowotwory złośliwe powiek - wyniki leczenia chirurgicznego i wybór metody rekonstrukcji. Nowotwory J Oncol 2012; 62: 431-7.

4. Cook BE, Bartley GB. Treatment options and future prospects for the management of eyelid malignancies. Ophthalmology 2001; 108: 2089-98.

5. Donaldson MJ, Sullivan TJ, Whitehead KJ, et al. Squamous cell carcinoma of the eyelids. Br J Ophthalmol 2002; 86: 1161-5.

6. Shields JA, Demirci H, Marr BP, et al. Sebaceous carcinoma of the ocular region: a review. Surv Ophthalmol 2005; 50: 103-22.

7. Vaziri M, Buffam FV, Martinka M, et al. Clinicopathologic features and behavior of cutaneous eyelid melanoma. Ophthalmology 2002; 109: 901-8.

8. LeBoit PE, Burg G, Weedon D, et al. Pathology and genetics of skin tumours. IARC Press. Lyon, France 2006.

9. Allali J, Hermies FD, Renard G. Basal cell carcinomas of the eyelids. Ophthalmologica 2005; 219: 57-71.

10. Szewczyk MP, Pazdrowski J, Dańczak-Pazdrowska A, et al Analysis of selected recurrence risk factors after treatment of head and neck basal cell carcinoma. Adv Dermatol Allergol 2014; 31: 146-51.

11. Crowson AN, Magro CN, Mihim MC. Biopsy interpretation of the skin. Wolters Kluwer/Lippincott Williams \& Wilkins, Philadelphia 2010.

12. Ohara M, Sotozono C, Tsuchihashi Y, et al. Ki-67 labeling index as a marker of malignancy in ocular surface neoplasms. Jpn J Ophthalmol 2004; 48: 524-9.

13. Janisson-Dargaud D, Durlach A, Lorenzato M, et al. Aneuploidy, but not Ki-67 or EGFR expression, is associated with recurrences in basal cell carcinoma. J Cutan Patol 2008; 35: 916-21.

14. Reszeć J, Kańczuga-Koda L, Sułkowska M, et al. An evaluation of Ki-67 and PCNA expression in conjunctival and eyelid tumors. Folia Morphol 2004; 63: 95-8.

15. Walker P, Hill D. Surgical treatment of basal cell carcinomas using standard postoperative histological assessment. Australas I Dermatol 2006; 47: 1-12.

16. Santiago F, Serra D, Vieira R, et al. Incidence and factors as sociated with recurrence after incomplete excision of basal cell carcinomas: a study of 90 cases. J Eur Acad Dermatol Venereol 2014; 24: 1421-4.

17. Bartoš V, Pokorný D, Zacharová O, et al. Recurrent basal cell carcinoma: a clinicopathological study and evaluation of histomorphological findings in primary and recurrent lesions. Acta Dermatoven APA 2011; 20: 67-75.

18. Boulinguez S, Grison-Tabone C, Lamant L, et al. Histological evolution of recurrent basal cell carcinoma and therapeutic implications for incompletely excised lesions. Br J Dermatol 2004; 151: 623-6.

19. Silverman MK, Kopf AV, Grin CM, B et al. Recurrence rates of treated basal cell carcinomas. Part 2: curretage-electrodessication. J Dermatol Surg Oncol 1994; 17: 720-6.

20. Berlin J, Katz KH, Helm KF, et al. The significance of tumor persistence after incomplete excision of basal cell carcinoma. J Am Acad Dermatol 2002; 46: 549-53.
21. Nouri K, Spencer JM, Taylor JR, et al. Does wound healing contribute to the eradication of basal cell carcinoma following curettage and electrodesiccation? Dermatol Surg 1999; 25: 183-8.

22. Sexton M, Jones DB, Maloney ME. Histologic pattern analysis of basal cell carcinoma. J Am Acad Dermatol 1990; 23: $1118-26$.

23. Zagrodnik B, Kempf W, Seifert B, et al. Superficial radiotherapy for patients with basal cell carcinoma: recurrence rates, histologic subtypes, and expression of p53 and Bcl-2. Cancer 2003; 98: 2708-14.

24. Stachura J, Domagała W. Patologia znaczy słowo o chorobie. Tom I. Polska Akademia Umiejętności. Krakow, 2008. 